\title{
Chemical Profile and Antioxidant Properties of Andrographis producta (C. B. Clarke) Gamble
}

\author{
Dayanand Dalawai, Hosakatte Niranjana Murthy*
}

\section{Dayanand Dalawai, Hosakatte Niranjana Murthy*}

Department of Botany, Karnatak University Dharwad 580003, INDIA.

\section{Correspondence}

\section{Hosakatte Niranjana Murthy}

Department of Botany, Karnatak University, Dharwad 580003, INDIA

E-mail: hnmurthy60@gmail.com

History

- Submission Date: 24-10-2020;

- Review completed: 11-12-2020.

- Accepted Date: 30-12-2020

DOI : 10.5530/pj.2021.13.60

Article Available online

http://www.phcogj.com/v13/i2

Copyright

(C) 2021 Phcogj.Com. This is an openaccess article distributed under the terms of the Creative Commons Attribution 4.0 International license.

\section{ABSTRACT}

Background: Andrographis producta (Acanthaceae) is endemic to Western Ghats, India, traditionally used by native people for the control of various ailments including intestinal worms, to relieve constipation and also used to eliminate phlegm in women during postpartum. Objective: To investigate the chemical compounds in root, stem and leaves of $A$. producta and their antioxidant properties. Method: The phytochemical contents were determined using spectrophotometric methods and chemical profiling of root, stem and leaf extracts was carried out using GC-MS. Further, extracts were investigated for their antioxidant capacities using in vitro DPPH radical scavenging and FRAP assay. Results: The total phenolics (163.61 $\mathrm{mg} \mathrm{GAE} / \mathrm{g})$, flavonoids $(35.11 \pm 0.53 \mathrm{mg} \mathrm{QE} / \mathrm{g})$ and tannins $(84.52 \pm 0.07 \mathrm{mg}$ TAE/g) were highest in stem compared to leaf and root. Stem was exerted superior antioxidant capacities in both DPPH (EC $\left.\mathrm{E}_{50} 3.58 \mathrm{mg} / \mathrm{ml}\right)$ and FRAP assays $(1.742 \pm 0.02 \mathrm{OD}$ at $1 \mathrm{mg} / \mathrm{ml})$ and were comparable to standards. GC-MS analysis revealed total 89 chemical compounds including phenolics, flavonoids, terpenoids and organic acids. 2-Methoxy-4-vinylphenol (0.70\%), 2,4-ditert-butylphenol (9.74 \%), phytol (10.32\%), 5-hydroxy-7,8-dimethoxyflavone (11.42\%), gammasitosterol (8.32\%), salvigenin (12.09\%), solanesol, (2.92\%), and alpha-terpinene (4.58\%) were important bioactive compounds found in significant amount. Conclusion: The present investigations indicate that various parts of $A$. producta can be explored as good source of antioxidants due to the presence of phenolics and flavonoids. The meticulous assessment of bioactive compounds from $A$. producta would be great contribution in field of medicine.

Key words: Andrographis, Antioxidants, GC-MS, Methanol extract, 2,4-Di-tert-butylphenol, Salvigenin.

\section{INTRODUCTION}

Andrographis Wall. ex Nees (Family Acanthaceae) consisting 45 species globally according to International Plant Name Index (IPNI) ${ }^{1}$ and 28 species in India where most of them have distributional range in South Indian states namely Karnataka, Tamil Nadu, Kerala and Andhra Pradesh., ${ }^{2,3}$ Andrographis paniculata Nees (Kalmegh) is therapeutically well known species in the genus distributed throughout India and other South East Asian countries. Kalmegh has been used to treat fever, cough, sore throat, gastric infections and other acute diseases and is as prime ingredient in several Ayurvedic formulations. ${ }^{4}$ The plant possesses wide range of pharmacological effects including antimalarial, anticancer, antioxidative, anti-inflammatory, antidiabetic, immunomodulatory and antiretroviral activities. Andrographolide is major diterpene lactone in the plant and neoandrographolide, 14-deoxy11,12-didehydroandrographolide, andrographon, 14-deoxyandrographolide are other bioactive compounds contributing to pharmacological activities together with some flavonoids. ${ }^{4,5}$

Andrographis producta (C. B. Clarke) Gamble is an undershrub reaching $150 \mathrm{~cm}$ in height. It is indigenous to South Indian states namely Karnataka, Kerala and Tamil $\mathrm{Nadu}^{2}$ and grows frequently in the edges of shola forests and often high elevated hill forests. The leaves are lanceolate-elliptic, acute-acuminate, sub-membranous, strigose on adaxial surface, $10-20 \mathrm{~cm}$ in long. The inflorescence is branched, rather terminal panicle with purplish white flowers. Corolla decurved, with a prominent ventricose protuberance.

Modern technologies and scientific advancements have been facilitating the discovery of synthetic drugs which helped in the treatment and control of even dreadful diseases but prolonged medication of synthetic drugs may lead to toxic side effects in human. The demand for the herbal based medicines, pharmaceuticals, nutraceuticals, food supplements and herbal cosmetics is growing worldwide due to the numerous benefits including non-toxicity, less/ no side effects, better compatibility with human physiology and affordable costs over synthetic drugs. ${ }^{6}$ Hence, identification of ethnopharmacologically important plants and extraction, isolation and characterization of chemical compounds using sophisticated chromatography techniques such as GC-MS, LC-MS and HPLC methods can help to find out biologically active compounds.

Andrographis producta is lesser known medicinally important plant of the genus used by tribal/native people in the Western Ghats region where it has been called with regional name 'Chevidantu'. The plant has 
been used to treat skin diseases. ${ }^{7}$ During the present study, we found that the leaf decoction is used to relieve the constipation, to control the intestinal worms in children and also used to eliminate phlegm in women during postpartum. Though species belongs to the medicinally important genus, the investigation on the chemical composition, antioxidant properties and pharmacological activities have not been carried out till date. Hence, in the present work, an attempt has been made to explore the chemical compounds present in the different parts of the plant i.e. root, stem and leaves using spectrophotometric and GCMS technique. Further, antioxidant potential of root, stem and leaves has been assessed by DPPH free radicals scavenging and FRAP assays to gather comprehensive information. Therefore, the present study aimed to investigate the available chemical compounds in root, stem and leaves of $A$. producta and their antioxidant properties.

\section{MATERIALS AND METHODS}

\section{Plant materials}

The plant materials of Andrographis producta were collected from Bababudan Hill range (Lat: $13^{\circ} 25^{\prime} 10.2108^{\prime \prime}$ Long: $75^{\circ} 44^{\prime} 37.0026^{\prime \prime}$; MSL $1467.30 \mathrm{~m}$ ), Chikkamagaluru district, Karnataka, India. Plants were identified by using Flora of British India and voucher specimen (DSD-06A) was deposited at Herbarium (SUK), Shivaji University, Kolhapur, India.

\section{Chemicals and reagents}

Analytical grade chemicals were used throughout the experiments. Methanol, ferric chloride $\left(\mathrm{FeCl}_{3}\right)$, sodium carbonate $\left(\mathrm{Na}_{2} \mathrm{Co}_{3}\right)$, sodium nitrite $\left(\mathrm{NaNO}_{2}\right)$, aluminum chloride $\left(\mathrm{AlCl}_{3}\right)$, hydrochloric acid $(\mathrm{HCl})$, 2,2-diphenyl-1-picrylhydrazyl (DPPH), 2, 4, 6-tripyridyl-s-triazine (TPTZ), ascorbic acid, butylated hydroxyl anisole (BHA), and FolinCoicalteu (FC) reagents were procured from HiMedia Laboratories Pvt. Ltd. (Mumbai, India). Gallic acid (GA), quercetin, tannic acid (TA) and Folin-Denis (FD) reagent were purchased from Sigma Aldrich Chemical Co. (USA).

\section{Preparation of extracts}

The plants were separated into different parts viz. root, stem and leaves were shade dried and ground to a coarse powder in blender followed by drying at $35^{\circ} \mathrm{C}$ in hot air over $24 \mathrm{~h} .10 \mathrm{~g}$ powder of each material was extracted with $100 \mathrm{ml}$ methanol individually with Soxhlet extractor at $55-60{ }^{\circ} \mathrm{C}$ for $8 \mathrm{~h}$. The extracts of root, stem and leaf were dried to evaporate the excess solvent using rotary evaporator under reduced pressure at $40{ }^{\circ} \mathrm{C}$ and used in experiments.

\section{Quantification of phytochemicals}

\section{Determination of total phenolics}

The amount of total phenolics in the methanolic extracts of root, stem and leaf was analyzed spectrophotometrically, as described by Folin and Ciocalteau ${ }^{8}$ with slight modifications. The methanolic extracts $(0.5$ $\mathrm{ml}$ ) were taken in test tubes containing $2.5 \mathrm{ml}$ of deionized distilled water and mixed with $0.1 \mathrm{ml}(2 \mathrm{~N})$ of Folin-Ciocalteau $(\mathrm{FC})$ reagent. The mixture was allowed to stand for $6 \mathrm{~min}$ before adding $0.5 \mathrm{ml}$ of 20 $\%$ sodium carbonate solution. The absorbance of the developed color after $30 \mathrm{~min}$ of incubation at room temperature was detected at $760 \mathrm{~nm}$ on UV visible spectrophotometer (UV-1601, Shimadzu). The amount of total phenolic content was calculated by comparing to the standard curve of gallic acid and expressed as the mg gallic acid equivalent (GAE) per g of dry samples.

\section{Determination of flavonoids}

The flavonoid content in the extracts of root, stem and leaf was determined spectrophotometrically ${ }^{9}$ with some modifications. $0.5 \mathrm{ml}$ of methanolic extracts of each samples were mixed with $2.5 \mathrm{ml}$ of distilled water and solution of $0.15 \mathrm{ml}$ sodium nitrite (5\%) was added to take place reaction for $6 \mathrm{~min}$. Then, $0.3 \mathrm{ml}$ of $10 \%$ aluminum chloride was added to take up the reaction for further $5 \mathrm{~min}$. Finally, $2 \mathrm{ml}$ of $1 \mathrm{M}$ sodium hydroxide was mixed and absorbance was read immediately on a spectrophotometer (UV-1601, Shimadzu) at $510 \mathrm{~nm}$. The standard calibration curve of quercetin was used to determine the amount of flavonoid contents and expressed as mg of quercetin equivalent $(\mathrm{QE})$ per $g$ of dry samples.

\section{Determination of tannins}

The methanolic extracts were used in determination of tannins present in the samples by spectrophotometrically according to the method developed by Schenderi. ${ }^{10}$ Each extracts $(0.5 \mathrm{ml})$ were mixed with 2.5 $\mathrm{ml}$ of distilled water and $0.25 \mathrm{ml}$ of Folin-Denis reagent, followed by $0.5 \mathrm{ml}$ of $30 \%$ sodium carbonate. Then all the reagents were mixed well to complete reaction and incubated for $30 \mathrm{~min}$ at room temperature. The absorbance of developed color was measured at $700 \mathrm{~nm}$ using spectrophotometer (UV-1601, Shimadzu). The known amount of tannic acid was used to draw the calibration curve and amount of tannin in samples determined and expressed as mg of tannic acid equivalent (TAE) per gram of dry samples.

\section{Gas chromatography and mass spectrometry (GC-MS) analysis}

Gas chromatography and mass spectrometry (Model: QP2010S; Shimadzu Corporation, Japan), a sophisticated analytical instrument equipped with Rxi-5Sil MS capillary column (length $30 \mathrm{~m} \times 0.25 \mathrm{~mm}$ ID, $0.25 \mu \mathrm{m}$ film thickness) was used to separate the chemical compounds present in the methanolic extracts of the samples. Helium (99.9995 \%) was the carrier gas with a constant flow rate of $1 \mathrm{ml} / \mathrm{min}$. the column oven temperature was held at $60^{\circ} \mathrm{C}$ initially and increased to $260^{\circ} \mathrm{C}$ by $5^{\circ} \mathrm{C} / \mathrm{min}$ held for $5 \mathrm{~min}$. The diluted samples of $1 \mu \mathrm{l}$ were injected in the split injection mode and the solvent delay was $4 \mathrm{~min}$. The total run time was of $30 \mathrm{~min}$. The ion source and interface line temperatures were set at $200{ }^{\circ} \mathrm{C}$ and $280{ }^{\circ} \mathrm{C}$, respectively. ${ }^{11}$ The separated components were identified by comparing the retention times of authentic compounds and mass spectra from NIST 11 \& WILEY 8 mass spectral libraries.

\section{In vitro antioxidant capacities}

\section{DPPH radicals scavenging assay}

The free radical scavenging activity of the extracts was measured in vitro by 2, 2-diphenyl-1-picryl hydrazyl (DPPH) assay. ${ }^{12}$ The stock solution was prepared with $24 \mathrm{mg}$ DPPH in $100 \mathrm{ml}$ methanol. The working solution was obtained by diluting DPPH stock solution with methanol to attain an absorbance of about $0.99 \pm 0.02$ at $515 \mathrm{~nm}$ on spectrophotometer (UV-1601, Shimadzu). Aliquots $(3 \mathrm{ml})$ of this working solution (DPPH) were mixed with $0.1 \mathrm{ml}$ sample of various concentrations $(0.2-1 \mathrm{mg} / \mathrm{ml})$. The reaction mixture was shaken well and incubated in the dark for $30 \mathrm{~min}$ at room temperature. Then the absorbance was recorded at $515 \mathrm{~nm}$. Simultaneously, the control was prepared without any sample. ascorbic acid and butylated hydroxyl anisole (BHA) were used as standards. The percentage of DPPH scavenging activity was calculated using the following equation.

Percentage of DPPH scavenging activity =

OD of control -OD of sample

OD of control $\times 100$

\section{Ferric reducing ability of plasma (FRAP) assay}

The FRAP assay was carried out according to the method developed by Benzie and Strain. ${ }^{13}$ The different concentration $(0.2-1.0 \mathrm{mg} / \mathrm{ml})$ of 0.1 $\mathrm{ml}$ plant extracts were added to $3 \mathrm{ml}$ of freshly prepared FRAP reagent 
(300 mM acetate buffer at $\mathrm{pH} 3.6,10 \mathrm{mM} \mathrm{2,} \mathrm{4,} \mathrm{6-tripyridyl-s-triazine}$ (TPTZ) in $40 \mathrm{mM} \mathrm{HCl}$ and $20 \mathrm{mM} \mathrm{FeCl}_{3}$ in the ratio 10:1:1) and heated to $37^{\circ} \mathrm{C}$ in an hot water bath for $10 \mathrm{~min}$. Final volume was adjusted to 4 $\mathrm{ml}$ using distilled water and incubated in the dark at room temperature for $10 \mathrm{~min}$. Optical density was measured at $593 \mathrm{~nm}$. Ascorbic acid and butylated hydroxyl anisole were used as standards. The increase in the optical density (OD) indicated greater the antioxidant power.

All experiments were conducted in triplicates using three different lots. Mean, percentage, $\mathrm{EC}_{50}$ values and standard deviations were calculated using Microsoft Office Excel 2007.

\section{RESULTS}

\section{Phytochemical analysis}

The phytochemicals such as total phenolics, flavonoids and tannins were quantified in the root, stem and leaves of $A$. producta and expressed as gallic acid equivalent (GAE), quercetin equivalent (QE) and tannic acid equivalent (TAE), respectively. Amount of total phenolics, flavonoids and tannins in the root extract were $94.60 \pm 0.51 \mathrm{mg} / \mathrm{g} \mathrm{DW}, 33.50$ $\pm 0.51 \mathrm{mg} / \mathrm{g}$ DW and $70.11 \pm 0.12 \mathrm{mg} / \mathrm{g}$ DW respectively. The stem extract comprised of $163.61 \pm 0.45 \mathrm{mg} / \mathrm{g}$ DW of phenolics, $35.11 \pm$
$0.53 / \mathrm{g}$ DW of flavonoids and $84.52 \pm 0.07 \mathrm{mg} / \mathrm{g}$ DW of tannins. The spectrophotometric quantifications affirmed that $109.75 \pm 0.10 \mathrm{mg}$ GAE/g DW of phenolics in higher proportion followed by $74.78 \pm 0.27$ $\mathrm{mg} / \mathrm{g}$ DW of tannins and $32.26 \pm 0.96 \mathrm{mg} / \mathrm{g}$ DW of flavonoids in the leaves of A. producta.

\section{Gas chromatography and mass spectrometry (GC-MS) analysis}

GC-MS analysis was performed to get insight into chemical profiles of root, stem and leaves of $A$. producta. Chromatograms of root, stem and leaf extracts (Figure 1) revealed that 30 (Table 1), 28 (Table 2) and 64 (Table 3) spectral peaks, respectively.

2-monopalmitin (12.20\%), 5-hydroxy-7,8-dimethoxyflavone (11.42\%), salvigenin (11.06 \%), 2,4-di-tert-butylphenol (9.74\%), trans-cinnamic acid (8.34\%), gamma-sitosterol (8.32\%), alpha-monostearin (7.44 $\%)$ and asaraldehyde (5.60 \%) were the prime chemical compounds constituted $74.12 \%$ of the methanolic extract of roots of $A$. producta (Table 1, Figure 1A).

Methanolic extract of stem sample composed of salvigenin (12.09\%), 2-monopalmitin (10.62\%), 2,4-di-tert-butylphenol (8.79\%), phytol

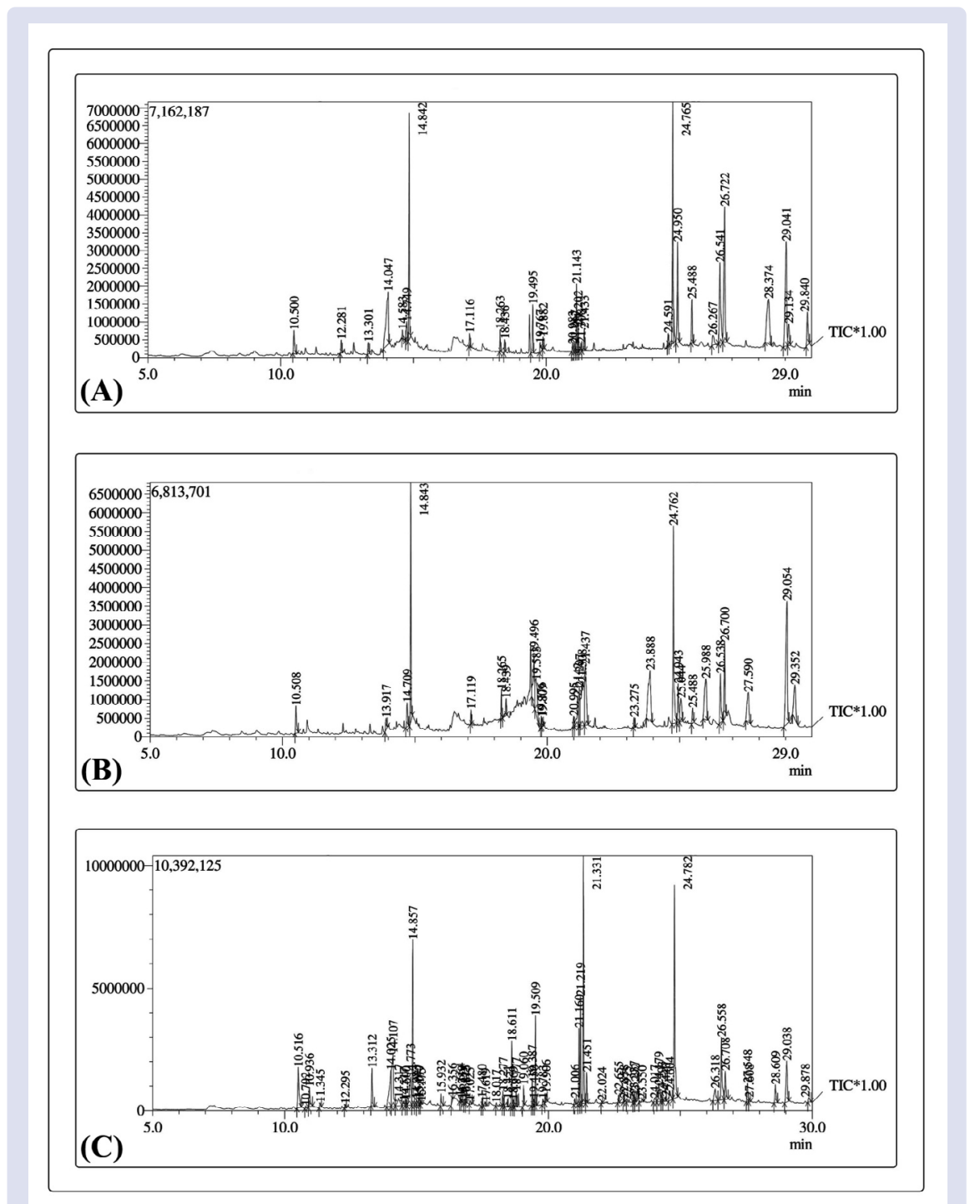

Figure 1: Chromatograms of gas chromatography and mass spectrometry (GC-MS) analysis of (A) root extract; (B) stem extract and (C) leaf extract. 
Table 1: GC-MS analysis of Andrographis producta root.

\begin{tabular}{|c|c|c|c|}
\hline SI. No. & Chemical compounds & Retention Time & Peak Area (\%) \\
\hline 1 & Azulene & 10.500 & 1.88 \\
\hline 2 & 2-Methoxy-4-vinylphenol & 12.281 & 0.70 \\
\hline 3 & Methyl cinnamate & 13.301 & 0.62 \\
\hline 4 & trans-Cinnamic acid & 14.047 & 8.34 \\
\hline 5 & Octadecane & 14.583 & 0.38 \\
\hline 6 & 1,2,3,5,6,8-Hexahydro-4,7-azulenedione & 14.749 & 1.39 \\
\hline 7 & 2,4-di-tert-butylphenol & 14.842 & 9.74 \\
\hline 8 & Eicosane & 17.116 & 0.65 \\
\hline 9 & 3-Heptadecanol & 18.263 & 0.95 \\
\hline 10 & Isopropyl myristate & 18.436 & 0.52 \\
\hline 11 & Hexadecanoic acid, methyl ester & 19.495 & 2.14 \\
\hline 12 & 3-Ethyl-3-pentanol & 19.767 & 0.70 \\
\hline 13 & Eicosanoic acid & 19.882 & 0.60 \\
\hline 14 & 1-Butylcyclohexanol & 20.983 & 0.39 \\
\hline 15 & 1-Octadecanol & 21.067 & 0.34 \\
\hline 16 & Methyl octadeca-9,12-dienoate & 21.143 & 2.78 \\
\hline 17 & 9-Octadecenoic acid (z)-, methyl ester & 21.202 & 1.15 \\
\hline 18 & Phytol & 21.308 & 0.45 \\
\hline 19 & Octadecanoic acid, methyl ester & 21.433 & 1.21 \\
\hline 20 & Hexanoic acid, pentadecyl ester & 24.591 & 0.67 \\
\hline 21 & 2-Monopalmitin & 24.765 & 12.20 \\
\hline 22 & Asaraldehyde & 24.950 & 5.60 \\
\hline 23 & Acetosyringone & 25.488 & 2.41 \\
\hline 24 & 6,11-Hexadecadien-1-ol & 26.267 & 1.18 \\
\hline 25 & alpha-Monostearin & 26.541 & 7.44 \\
\hline 26 & 5-Hydroxy-7,8-dimethoxyflavone & 26.722 & 11.42 \\
\hline 27 & gamma-Sitosterol & 28.374 & 8.32 \\
\hline 28 & Salvigenin & 29.041 & 11.06 \\
\hline 29 & L-Phenylalanine, n-heptafluorobutyryl-, hexadecyl ester & 29.134 & 1.85 \\
\hline 30 & Solanesol & 29.840 & 2.92 \\
\hline
\end{tabular}

(7.88 \%), butylphosphonic acid, butyl 4-(2-phenylprop-2-yl) phenyl ester (7.48\%), methyl 8,10-dimethyl-hexadecanoate (6.07\%) and 4-acetoxy-6',7-dimethyl-5',8'-dimethoxy-1,2'-binaphthalene-1',4',5,8tetrone $(5.19 \%)$ as major compounds (Table 2, Figure 1B).

The GC-MS results of leaf sample are presented in Table 3, the large number of spectral peaks (i.e. 64 compounds) were detected in the leaf, compared to root and stem (Figure 1C). 2-monopalmitin (12.13 $\%)$ and phytol (10.32\%) were highest in the proportion followed by 2,4-di-tert-butylphenol (7.43\%) and trans-cinnamic acid (5.74 $\%)$. The octadecanoic acid, 2, 3-dihydroxypropyl ester (4.48\%), 9,12,15-octadecatrienoic acid, methyl ester (4.19\%) and alphaterpinene $(4.58 \%)$ were also present in appreciable quantity.

\section{In vitro antioxidant capacities}

\section{DPPH radicals scavenging assay}

DPPH free radicals were deep purple colored due to their lone pair of electrons and the antioxidants present in the samples scavenge the lone pair of electrons that decolorize the DPPH containing solution. Thus, the decreasing in the purple color is directly linked to the antioxidant potential of methanolic extracts of the samples. The concentration dependent scavenging activity against DPPH radicals was expressed in $\mathrm{mg} / \mathrm{ml} \mathrm{EC}_{50}$ value (Figure $2 \mathrm{~A}$ ). The lower the $\mathrm{EC}_{50}$ value indicated higher the radical scavenging activity and vice versa. The methanolic extracts of root, stem and leaf exhibited DPPH radical scavenging capacity with $\mathrm{EC}_{50}$ value of $5.02 \mathrm{mg} / \mathrm{ml}, 3.58 \mathrm{mg} / \mathrm{ml}$ and $7.02 \mathrm{mg} / \mathrm{ml}$ respectively, which were less than ascorbic acid $(2.85 \mathrm{mg} / \mathrm{ml})$ and BHA $(3.22 \mathrm{mg} / \mathrm{ml})$ (Figure 2A).

\section{Ferric reducing ability of plasma (FRAP) assay}

FRAP assay was rapid and sensitive to assess antioxidant power with a range of concentration. Under low $\mathrm{pH}$, the colorless ferrictripyridyltriazine $\left(\mathrm{Fe}^{3+}\right.$-TPTZ) complex reduced to an intense blue complex, ferrous-tripyridyltriazine $\left(\mathrm{Fe}^{2+}-\mathrm{TPTZ}\right)$ by the antioxidants present in the sample on dose-response relationship. The higher in the color development indicated more amount of antioxidants. Antioxidant power of standard ascorbic acid and BHA reached maximum efficacy at low concentration i.e. $1.986 \pm 0.02$ OD. at $0.2 \mathrm{mg} / \mathrm{ml}$ and $2.116 \pm 0.04$ $\mathrm{OD}$ at $0.4 \mathrm{mg} / \mathrm{ml}$ respectively, but dose-response of each samples tested was linear (Figure $2 \mathrm{~B}$ ) with change in concentration. The methanolic extracts of stem showed good antioxidant power i.e. $0.63 \pm 0.015$ $\mathrm{OD}$ and $1.742 \pm 0.02 \mathrm{OD}$ at $0.2 \mathrm{mg} / \mathrm{ml}$ and $1 \mathrm{mg} / \mathrm{ml}$ of concentration respectively. The order of antioxidant power of samples was stem $>$ root $>$ leaf (Figure 2B).

\section{DISCUSSION}

Herbal products of Andrographis paniculata are in higher demands in herbal and phamceutical market and it amounts to 2197.3 tons per year (in the year 2005-2006). ${ }^{14}$ It has been highly traded and prioritized medicinal plant in the Asian countries that has lead to decline in the availability of natural populations. ${ }^{14,15}$ The over-exploitations of $A$. paniculata have created the necessity to search for alternatives to relieve the burden. In present study, we quantified the total phenolics, flavonoids and tannins in root, stem and leaf from $A$. producta. The total phenolics (163.61 mg GAE/g), flavonoids (35.11 $\pm 0.53 \mathrm{mg} \mathrm{QE} / \mathrm{g}$ ) and tannins $(84.52 \pm 0.07 \mathrm{mg}$ TAE/g) were highest in stem compared 
Table 2: GC-MS analysis of Andrographis producta stem.

\begin{tabular}{|c|c|c|c|}
\hline SI. No. & Chemical compounds & Retention Time & Peak Area (\%) \\
\hline 1 & Azulene & 10.508 & 1.73 \\
\hline 2 & trans-Cinnamic acid & 13.917 & 0.71 \\
\hline 3 & $1,2,3,5,6,8$-Hexahydro-4,7-azulenedione & 14.709 & 1.55 \\
\hline 4 & 2,4-di-tert-butylphenol & 14.843 & 8.79 \\
\hline 5 & Eicosane & 17.119 & 0.49 \\
\hline 6 & 3-Heptadecanol & 18.265 & 1.09 \\
\hline 7 & Isopropyl myristate & 18.439 & 0.69 \\
\hline 8 & Hexadecanoic acid, methyl ester & 19.496 & 4.05 \\
\hline 9 & 4-Tert-Butylcatechol, Bis (Trifluoroacetate) & 19.583 & 4.57 \\
\hline 10 & 3-Ethyl-3-pentanol & 19.776 & 0.36 \\
\hline 11 & 2,6,10,14-Tetramethyl-hexadecane, & 19.809 & 0.32 \\
\hline 12 & 1-Butylcyclohexanol & 20.995 & 0.50 \\
\hline 13 & 9,12-Octadecadienoic acid $(\mathrm{z}, \mathrm{z})-$, methyl ester & 21.142 & 2.81 \\
\hline 14 & Hexadecadienoic acid, methyl ester & 21.207 & 2.09 \\
\hline 15 & Phytol & 21.308 & 7.88 \\
\hline 16 & Methyl 8,10-dimethyl-hexadecanoate or 8,10-dimethyl-16:0 & 21.437 & 6.07 \\
\hline 17 & Tetrapentacontane & 23.275 & 0.36 \\
\hline 18 & Butylphosphonic acid, butyl 4-(2-phenylprop-2-yl) phenyl ester & 23.888 & 7.48 \\
\hline 19 & 2-Monopalmitin & 24.762 & 10.62 \\
\hline 20 & Asaraldehyde & 24.943 & 2.26 \\
\hline 21 & L-Phenylalanine, n-pentafluoropropionyl-, octadecyl ester & 25.044 & 2.38 \\
\hline 22 & 1-[1,1'-Biphenyl]-3-yl-ethanone & 25.488 & 0.84 \\
\hline 23 & 4-Acetoxy-6',7-dimethyl-5',8'-dimethoxy-1,2'-binaphthalene-1',4',5,8-tetrone & 25.988 & 5.19 \\
\hline 24 & Octadecanoic acid, 2,3-dihydroxypropyl ester & 26.538 & 3.21 \\
\hline 25 & 5-Hydroxy-7,8-dimethoxyflavone & 26.700 & 4.31 \\
\hline 26 & Stigmasterol & 27.590 & 3.57 \\
\hline 27 & Salvigenin & 29.054 & 12.09 \\
\hline 28 & gamma-Sitosterol & 29.352 & 3.99 \\
\hline
\end{tabular}

Table 3: GC-MS analysis of Andrographis producta leaf.

$\begin{array}{cccc}\text { SI. No. } & \text { Retention Time } & \text { Peak Area (\%) } \\ 1 & \text { Chemical compounds } & 10.516 & 3.44 \\ 2 & \text { Azulene } & 10.792 & 0.06 \\ 3 & \text { 2-Propyl-1-heptanol } & 10.936 & 1.62 \\ 4 & 2,3 \text {-Dihydro-benzofuran } & 11.345 & 0.29 \\ 5 & \text { 2,4-Hexadiene, 3,4-Dimethyl-, (E,Z)- } & 12.295 & 0.19 \\ 6 & \text { 2-Methoxy-4-vinylphenol } & 13.312 & 1.95 \\ 7 & \text { m-Hydroxy cinnamic acid, methyl ester } & 14.025 & 4.58 \\ 8 & \text { alpha-Terpinene } & 14.107 & 5.74 \\ 9 & \text { Trans-Cinnamic acid } & 14.317 & 2.06 \\ 10 & \text { Adenosine, 1,2-dihydro-2-oxo- } & 14.517 & 0.51 \\ 11 & \text { Eicosane } & 14.600 & 0.29 \\ 12 & \text { 4-(2,6,6-Trimethylcyclohexa-1,3-dienyl) but-3-en-2-one } & 14.773 & 3.45 \\ 13 & \text { 1,2,3,5,6,8-Hexahydro-4,7-azulenedione } & 14.857 & 7.43 \\ 14 & \text { 2,4-di-tert-butylphenol } & 14.983 & 0.72 \\ 15 & \text { Nerolidyl acetate } & 15.077 & 0.50 \\ 16 & \text { Benzoic acid, 4-ethoxy-, ethyl ester } & 15.117 & 0.30 \\ 17 & 1 \text {-(2-Ethoxyphenyl) acetone } & 15.175 & 0.16 \\ 18 & \text { Farnesene Epoxide, E- } & 15.932 & 0.67 \\ 19 & \text { Megastigmatrienone } & 16.356 & 0.34 \\ 20 & \text { Naphthalene, decahydro-1,4-dimethoxy-,(1.alpha,4.beta,4a.alpha,8a.alpha)- } & 16.664 & 0.19 \\ 21 & \text { E-(6,6-Dimethyl-2-methylenecyclohex-3-enylidene)pentan-2-ol } & 16.719 & 0.09 \\ 22 & \text { beta-Ionol } & 16.825 & 0.21 \\ 23 & \text { Endo-1,5,6,7-tetramethylbicyclo[3.2.0] hept-6-en-3-ol } & 16.875 & 0.21 \\ 24 & \text { 1-Chlorohexadecane, } & 17.025 & 0.21 \\ 25 & \text { Unknown } & 17.480 & 0.34 \\ 26 & \text { Octadecane, 1-chloro- } & 17.619 & 0.21\end{array}$




\begin{tabular}{|c|c|c|c|}
\hline 27 & (-)-Loliolide & 18.017 & 0.33 \\
\hline 28 & 3-Heptadecanol & 18.277 & 0.61 \\
\hline 29 & Isopropyl myristate & 18.451 & 0.24 \\
\hline 30 & Neophytadiene & 18.611 & 2.53 \\
\hline 31 & 1-Dodecanol, 3,7,11-trimethyl- & 18.669 & 0.34 \\
\hline 32 & 3-Oxatricyclo[20.8.0.0(7,16)]Triaconta-1(22),7(16),9,13,23,29-Hexaene & 18.777 & 0.69 \\
\hline 33 & 3,7,11,15-Tetramethyl-2-hexadecen-1-ol & 19.060 & 0.76 \\
\hline 34 & 7,9-Di-tert-butyl-1-oxaspiro(4,5)deca-6,9-diene-2,8-dione & 19.387 & 1.16 \\
\hline 35 & Methyl palmitoleate & 19.450 & 0.27 \\
\hline 36 & Hexadecanoic acid, methyl ester & 19.509 & 3.47 \\
\hline 37 & 3-Ethyl-3-pentanol, & 19.783 & 0.33 \\
\hline 38 & 9-Octadecenoic acid (z)- & 19.906 & 0.54 \\
\hline 39 & 1-Butylcyclohexanol & 21.006 & 0.28 \\
\hline 40 & 9,12-Octadecadienoic acid, methyl ester & 21.160 & 3.12 \\
\hline 41 & 9,12,15-Octadecatrienoic acid, methyl ester & 21.219 & 4.19 \\
\hline 42 & Phytol & 21.331 & 10.32 \\
\hline 43 & Methyl stearate & 21.451 & 1.34 \\
\hline 44 & Geranyl-.alpha.-terpinene & 22.024 & 0.12 \\
\hline 45 & 6,9-Octadecadiynoic acid, methyl ester & 22.655 & 0.40 \\
\hline 46 & 3-Cyclopentylpropionic acid, 2-dimethylaminoethyl ester & 22.858 & 0.13 \\
\hline 47 & 2-Hexadecen-1-Ol, 3,7,11,15-tetramethyl-, [r-[r* $\left.\left.\mathrm{r}^{*} \mathrm{r}^{*}-(\mathrm{e})\right]\right]$ - (t-phytol) & 22.975 & 0.30 \\
\hline 48 & Docosanoic acid, methyl ester & 23.237 & 0.40 \\
\hline 49 & Tetrapentacontane & 23.292 & 0.24 \\
\hline 50 & Card-20(22)-Enolide, 3,5,14,19-tetrahydroxy-, (3.beta.,5.beta.)- & 23.550 & 0.13 \\
\hline 51 & Pinostrobin chalcone & 24.017 & 0.71 \\
\hline 52 & beta-Sitosterol & 24.179 & 2.49 \\
\hline 53 & Androstan-17-one, 3-ethyl-3-hydroxy-, (5.alpha.)- & 24.293 & 0.36 \\
\hline 54 & 1h-Indole-3-acetic acid & 24.440 & 0.32 \\
\hline 55 & 2-Ethylbutyric acid, eicosyl ester & 24.604 & 1.05 \\
\hline 56 & 2-Monopalmitin & 24.782 & 12.13 \\
\hline 57 & 1-Docosanol & 26.318 & 1.44 \\
\hline 58 & Octadecanoic acid, 2,3-dihydroxypropyl ester & 26.558 & 4.48 \\
\hline 59 & 5-Hydroxy-7,8-dimethoxyflavone & 26.708 & 2.08 \\
\hline 60 & Squalene & 27.548 & 1.19 \\
\hline 61 & Apigenin 7,4'-dimethyl ether & 27.608 & 0.28 \\
\hline 62 & 1-Heptacosanol & 28.609 & 1.28 \\
\hline 63 & Salvigenin & 29.038 & 3.76 \\
\hline 64 & 3-(4-Fluoro-phenyl)-5,5-dimethyl-4,5-dihydro-3h-2,3,6,11-tetraaza-cyclopenta[a]anthracene & 29.878 & 0.40 \\
\hline
\end{tabular}

Table 4: List of biologically important chemical compounds indentified in Andrographis producta by GC-MS.

\begin{tabular}{|c|c|c|c|c|}
\hline SI. No. & Chemical compounds & $\begin{array}{l}\text { Source of } \\
\text { compounds }\end{array}$ & Biological uses & Reference \\
\hline 1 & 2,4-Di-tert-butylphenol & Root, stem and leaf & $\begin{array}{c}\text { Anti-biofilm, anti-inflammatory and anticancer } \\
\text { effects }\end{array}$ & 18,19 \\
\hline 2 & 2-Methoxy-4-vinylphenol & Root, leaf & $\begin{array}{l}\text { Antimicrobial, anticancer and antiinflammatory } \\
\text { activity }\end{array}$ & $20,21,22$ \\
\hline 3 & $\begin{array}{l}\text { 5-Hydroxy-7,8-dimethoxyflavone or } \\
\text { 7-O-Methylwogonin }\end{array}$ & Root, stem and leaf & Anticancer agent & 23 \\
\hline 4 & alpha-Terpinene & Leaf & $\begin{array}{l}\text { Insecticidal, trypanocidal, } \\
\text { oxidative stress, cytotoxic and genotoxic effects }\end{array}$ & 2425,26 \\
\hline 5 & Apigenin 7,4'-dimethyl ether & Leaf & Antifungal activity & 27 \\
\hline 6 & Asaraldehyde & Root and stem & Antiobesity effects & 28 \\
\hline 7 & Azulene & Root, stem and leaf & Anti-inflammatory activity & 29 \\
\hline 8 & Cinnamic acid & Root, stem and leaf & $\begin{array}{l}\text { Antibactearial, antioxidant, anti-inflammatory, and } \\
\text { antidiabetic activity }\end{array}$ & $\begin{array}{l}30 \\
31 \\
32\end{array}$ \\
\hline 9 & gamma-Sitosterol & Root and stem & Hypolipidemic and anticancer activity & $\begin{array}{l}33 \\
34\end{array}$ \\
\hline
\end{tabular}




\begin{tabular}{|c|c|c|c|c|}
\hline 10 & Methyl cinnamate & Root & Larvicidal activity & 35 \\
\hline 11 & Neophytadiene & Leaf & Anti-inflammatory effects & 36 \\
\hline 12 & Phytol & Root, stem and leaf & $\begin{array}{l}\text { Anti-inflammatory and immune-modulating } \\
\text { properties }\end{array}$ & $\begin{array}{l}37 \\
38\end{array}$ \\
\hline 13 & Pinostrobin chalcone & Leaf & Anti-obesity effects & 39 \\
\hline 14 & Salvigenin & Root, stem and leaf & Neuroprotective effects & 40 \\
\hline 15 & Solanesol & Root & Neuroprotective effects and antioxidant activity & $\begin{array}{l}41 \\
42\end{array}$ \\
\hline 16 & Squalene & Leaf & Antitumor and antioxidant effects & 43 \\
\hline 17 & Stigmasterol & Stem & Anti-diabetic activity & 44 \\
\hline 18 & beta-Sitosterol & Leaf & $\begin{array}{l}\text { Anti bacterial, genotoxic, antioxidant and } \\
\text { antidiabetic effects }\end{array}$ & 45 \\
\hline
\end{tabular}
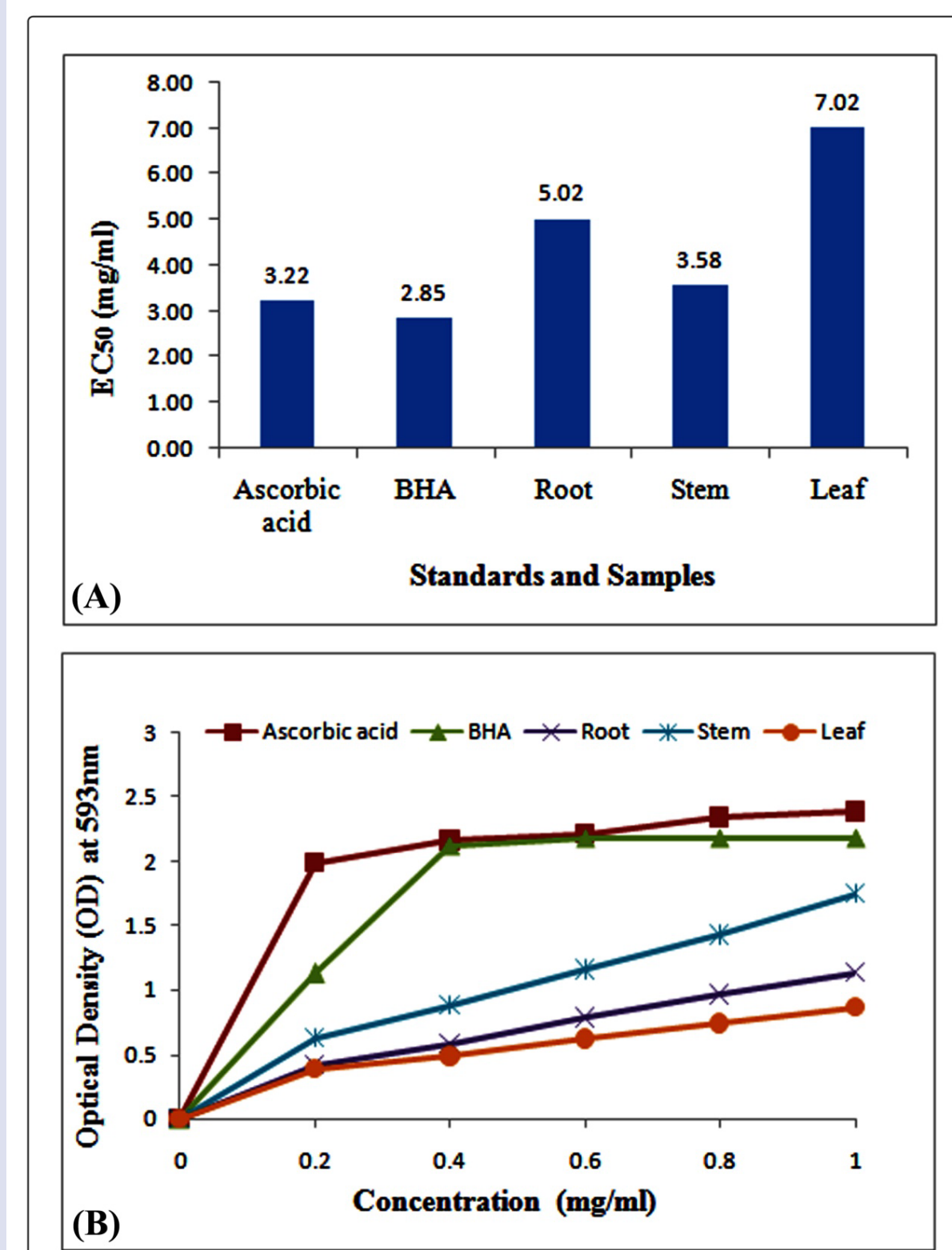

Figure 2: (A) DPPH radical scavenging activity of root, stem and leaf extracts of $A$. producta in comparison with ascorbic acid and BHA expressed in $\mathrm{EC}_{50}$ value $(\mathrm{mg} / \mathrm{ml})$; (B) FRAP antioxidant power of root, stem and leaf of A. producta (conc. $0.2-1.0 \mathrm{mg} / \mathrm{ml}$ concentration) in comparison with ascorbic acid and BHA expressed in Optical density (OD) at $593 \mathrm{~nm}$. 
to leaf and root. The total phenolic and tannins were relatively less in roots (i.e. $94.60 \pm 0.51 \mathrm{mg} \mathrm{GAE} / \mathrm{g}$ and $70.11 \pm 0.12 \mathrm{mg} \mathrm{TAE} / \mathrm{g}$, respectively) than the leaf (i.e. $109 \pm 0.10 \mathrm{mg} \mathrm{GAE} / \mathrm{g}$ and $74.78 \pm 0.27$ mg TAE/g, respectively) extract. Similarly, Rafat et al. ${ }^{16}$ reported the phenolic content variation in ethanolic extract of stem, leaf and fruits of $A$. paniculata which were $55.02 \pm 0.35 \mathrm{mg}$ of GAE/g, $75.86 \pm 0.82$ $\mathrm{mg}$ of GAE/g and $181.00 \pm 1.48 \mathrm{mg}$ of GAE/g respectively. However, amount of phenolic content was superior in stem (163.61 mg GAE/g) and leaf $(109 \pm 0.10 \mathrm{mg} \mathrm{GAE} / \mathrm{g})$ of $A$. producta compared to that of $A$. paniculata.

The polyphenols such as total phenolics and flavonoids derived from the plants have been more effective antioxidants. ${ }^{17}$ The DPPH radical scavenging activity was highest in the stem samples with $3.58 \mathrm{mg} /$ $\mathrm{ml} \mathrm{EC}_{50}$ value (Figure $2 \mathrm{~A}$ ) which was comparable to $\mathrm{EC}_{50}$ values of standard ascorbic acid $(3.22 \mathrm{mg} / \mathrm{ml})$ and BHA $(2.85 \mathrm{mg} / \mathrm{ml})$. The high amount of total phenolics (163.61 mg GAE/g) and flavonoids $(35.11 \pm 0.53 \mathrm{mg} \mathrm{QE} / \mathrm{g})$ were found in stem might have contributed to antioxidant effects. Root and leaf extracts were exhibited less radical scavenging activity than stem with $\mathrm{EC}_{50}$ values of $5.02 \mathrm{mg} / \mathrm{ml}$ and 7.02 $\mathrm{mg} / \mathrm{ml}$ of concentration respectively (Figure $2 \mathrm{~A}$ ). Further, FRAP assay affirmed the antioxidant effects of each sample as displayed by DPPH assay. The reduction of ferric-tripyridyltriazine $\left(\mathrm{Fe}^{3+}-\mathrm{TPTZ}\right)$ to ferroustripyridyltriazine $\left(\mathrm{Fe}^{2+}-\mathrm{TPTZ}\right)$ found highest in the solution of stem extract with $1.742 \pm 0.02$ OD (Figure 2B), whereas root $(1.139 \pm 0.03$ ) and leaf $(0.866 \pm 0.016)$ showed relatively less reduction of $\mathrm{Fe}^{3+}$-TPTZ (Figure 2B). The DPPH and FRAP assays have demonstrated that stem was rich reservoir of antioxidant compounds followed by root and leaf, and antioxidant capacities were attributed to total phenolics and flavonoids that are capable of donating hydrogen to free radicals to reduce oxidative stress (Figure 2).

The GC-MS analysis of $A$. producta revealed that the large number of chemical compounds present in the methanolic extracts of different parts. Total of 89 compounds were identified by GC-MS analysis, in which 14 compounds were common in all the three extracts, 2 compounds in root and stem, 2 compounds in stem and leaf and 1 compound in root and leaf extracts. However, 13, 10 and 47 compounds were specific to root, stem, and leaf extracts, respectively (Table 1,2 and 3). The GC-MS analysis showed the presence of several biologically active compounds are listed in Table 4 , including phenolics, flavonoids, terpenoids and organic acids. Azulene (3.44\%), 2-methoxy4-vinylphenol (0.70\%), cinnamic acid (8.34\%), 2,4-di-tert-butylphenol (9.74\%), phytol (10.32\%), 5-hydroxy-7,8-dimethoxyflavone (11.42\%), gamma-sitosterol (8.32\%), salvigenin (12.09\%), solanesol, (2.92\%), stigmasterol (3.57\%), and alpha-terpinene (4.58\%) were the important bioactive compounds found in significant amount in the root, stem and leaf.

Cinnamic acid is belongs to class of aromatic organic compounds and it was present in all three parts of $A$. producta i.e. root (8.34\%), stem (0.71 $\%)$ and leaf (5.74\%). The cinnamic acid was reported to exhibit in vivo anti-diabetic activity in Wistar rats. ${ }^{32}$ The administration of cinnamic acid at $10 \mathrm{mg} / \mathrm{kg}$ dose to non-obese type 2 diabetic rats had decreased the blood glucose level significantly on time and dose dependent mode and also, at $100 \mu \mathrm{M}$ concentration, triggered the insulin secretion efficiently ( $6.06 \pm 0.83 \mathrm{ng} /$ islet/hour) which was comparable to insulin secretion by standard drug tolbutamide $(6.56 \pm 0.81 \mathrm{ng} /$ islet/hour $){ }^{32}$ Alpha-Terpinene was detected in leaf $(4.58 \%)$ of $A$. producta belongs to group of monoterpenoids (Table 3). The investigation on the toxic effects of the alpha-terpinene in liver tissues of rats was conducted and showed that the hepatic damage caused by alpha-terpinene at a dose of $1.0 \mathrm{~mL}$ per $\mathrm{kg}$ was reported via quantitative elevation of serum ALT and AST activities. ${ }^{26}$ Therefore, alpha-terpinene could induce oxidative stress, cytotoxic and genotoxic damages in the hepatic tissue involving the caspases activation. ${ }^{26}$
2-Methoxy-4-vinylphenol is used as flavoring agent found in root $(0.70$ $\%)$ and leaves $(0.19 \%)$ of $A$. producta. 2-methoxy-4-vinylphenol was proved to be potent anticancer agent and suppressed migratory activity of pancreatic cancer cells, Panc-1 and SNU-213 and also reduced the viability of Panc- 1 cells by inhibiting the cell nuclear antigen expression. ${ }^{21}$ 2,4-Di-tert-butylphenol belongs to phenol group was isolated from roots of Humboldtia unijuga showed anticancer effects through the activation of p53 gene in breast cancer cell line i.e. MCF-7 and also, anti-inflammatory effects of 2, 4-di-tert-butylphenol were significantly superior in pro-inflammatory cytokines TNFa, IL-6 and IL-1b. ${ }^{19}$ Nair et al. ${ }^{19}$ suggested for the development of 2, 4-di-tert-butylphenol as a novel anti-inflammatory and anticancer agent. Further, significant amount of 2, 4-di-tert-butylphenol was detected in root $(9.74 \%)$, stem $(8.79 \%)$ and leaf $(7.43 \%)$ of A. producta. Accordingly, the antioxidant activity of A. producta have attributed to these compounds such as 2-methoxy-4vinylphenol and 2,4-di-tert-butylphenol due to the their capabilities of prevention of free radical mediated oxidation (Figure 2).

Solanesol is a terpene alcohol, which has absorbed the ultraviolet radiation effectively and inhibited the tyrosinae, a key enzyme in melanin synthesis and pigmentation disorder in human. ${ }^{42}$ In the neuroprotective assessment, salvigenin at the concentration of 25 $\mu \mathrm{M}$ decreased the oxidative stress induced apoptosis by activating antioxidant factors in neuroblastoma SH-SY5Y cells. ${ }^{40}$ GammaSitosterol belongs to class of organic compound had exhibited potential anticancer activity through the growth inhibition, cell cycle arrest at G2/M phase and the apoptosis on cancer cells. ${ }^{34}$ Solanesol, (2.92\%), salvigenin (12.09\%), and gamma-sitosterol (8.32\%) were found considerable mass in A. producta. However, several chemical compounds such as megastigmatrienone (0.34\%), 2-monopalmitin (12.20\%), acetosyringone (2.41\%), tetrapentacontane $(0.36 \%)$, butylphosphonic acid, butyl 4-(2-phenylprop-2-yl) phenyl ester $(7.48 \%)$, and (-)-loliolide, (0.33\%) belonging to classes of phenolics, sesquiterpenoids, isoprenoids, fatty acids, and benzofurans (Table 1. 2 and 3) are need to be scrutinized in details for their biological activities.

\section{CONCLUSION}

This is the first report on the quantification of total phenolic, flavonoid and tannin contents, identification of phytochemicals by GC-MS method and assessment of antioxidant capacities from Andrographis producta. The findings in the present investigation indicate that root, stem and leaf of $A$. producta can be explored as a good source of potent antioxidants due to the availability of phenolic and flavonoid contents. GC-MS studies showed the presence of important bioactive compounds such as cinnamic acid, 2,4-di-tert-butylphenol, solanesol, phytol, alphaterpinene, 5-hydroxy-7,8-dimethoxyflavone, salvigenin, stigmasterol and gamma-sitosterol and it provides immense opportunities to isolate and validate the phytochemicals for their pharmacological activities. Further, the meticulous assessment of such bioactive compounds from the A. producta would be great contribution in the field of medicine.

\section{ACKNOWLEDGEMENTS}

This work was supported by DST-PURSE-Phase-II program and UGCBSR mid-career award grant [No. F. 19-223/2018(BSR)]

\section{CONFLICTS OF INTEREST}

Authors declare no conflict of interest.

\section{ABBREVIATIONS}

ALT: Alanine Aminotransferase; AST: Aspartate Transaminase; BHA: Butylated Hydroxyl Anisole; DPPH: 2,2-Diphenyl-1-Picrylhydrazyl; DW: Dry Weight; $E_{50}$ : Effective Concentration 50; FRAP: Ferric Reducing Ability of Plasma; GAE: Gallic Acid Equivalent; GC-MS: 
Gas Chromatography-Mass Spectrometry; HPLC: High Performance Liquid Chromatography; ID: Inner Diameter; IL-1 $\beta$ : Interleukin-1 $\beta$; IL-6: Interleukin-6; LC-MS: Liquid Chromatography-Mass Spectrometry; MCF-7: Michigan Cancer Foundation-7; MSL: Mean Sea Level; OD: Optical Density; Panc-1: Pancreatic-1; QA: Quercetin Equivalent; SNU-213: Seoul National University-213; TAE: Tannic Acid Equivalent; TNF- $\alpha$ : Tumor Necrosis Factor- $\alpha$; TPTZ: 2, 4, 6-TripyridylS-Triazine; UV: Ultraviolet.

\section{REFERENCES}

1. IPNI. International Plant Names Index. Published on the Internet http://www.ipni.org, The Royal Botanic Gardens, Kew, Harvard University Herbaria \& Libraries and Australian National Botanic Gardens. [Retrieved 16 October 2020].

2. Nayar TS, Rasiya Beegam A, Mohanan N, Rajkumar G. Flowering plants of Kerala-A handbook. Tropical Botanic Garden and Research Institute, Thiruvananthapuram, Kerala. 2006;1.

3. Karthikeyan S, Sanjappa M, Moorthy S. Flowering plants of India Dicotyledons, (Acanthaceae - Avicenniaceae). Botanical Survey of India, Kolkata. 2009;1:1- 4

4. Subramanian R, Asmawi MZ, Sadikun A. A bitter plant with a sweet future? A comprehensive review of an oriental medicinal plant: Andrographis paniculata. Phytochem Rev. 2012;11:39-75.

5. Hossain MS, Urbi Z, Sule A, Hafizur RKM. Andrographis paniculata (Burm. f.) Wall. ex Nees: A review of ethnobotany, phytochemistry, and pharmacology. Sci World J. 2014;Article ID 274905, 28 pages.

6. Sen S, Chakraborty R, De B. Challenges and opportunities in the advancement of herbal medicine: India's position and role in a global context. J Herb Med. 2011;1:67-75.

7. Ponnusamy S, Arumugam R, Ariyan S, Chinnaiyan R. Ethnobotanical knowledge of threatened plant species Andrographis in Nilgiris biosphere reserve, Tamil Nadu, India. Int J Herb Med. 2017;5:103-7.

8. Folin $\mathrm{O}$, Ciocalteu V. On tyrosine and tryptophane determinations in proteins. J Biol Chem. 1927;73:627-50.

9. Wu X, Prior RL, Schaich K. Standardised methods for the determination of antioxidant capacity and phenolics in foods and dietary supplements. J Agric Food Chem. 2005;53:4290-302.

10. Schanderi SH. Methods in food analysis. Academic press, New York, USA: 1970

11. Roy S, Rao K, Bhuvaneswari C, Giri A, Mangamoori LN. Phytochemical analysis of Andrographis paniculata extract and its antimicrobial activity. World J Microbiol Biotechnol. 2010;26:85-91.

12. Brand-WilliamsW, Cuvelier ME, Berset $C$. Use of a free radical method to evaluate antioxidant activity. LWT-Food Sci Technol. 1995;28:25-30.

13. Benzie IF, Strain JJ. The ferric reducing ability of plasma (FRAP) as a measure of "Antiocidant power": The frap assay. Anal Biochem. 1996;239:70-6.

14. Valdiani A, Kadir MA, Tan SG, Talei D, Abdullah MP, Nikzad S. Nain-e Havandi Andrographis paniculata present yesterday, absent today: a plenary review on underutilized herb of Iran's pharmaceutical plants. Mol Biol Rep. 2012;39:5409-24

15. Kala CP, Dhyani PP, Sajwan BS. Developing the medicinal plants sector in northern India: challenges and opportunities. J Ethnobiol Ethnomed 2006;2:32.

16. Rafat A, Philip K, Muniandy S. Antioxidant potential and content of phenolic compounds in ethanolic extracts of selected parts of Andrographis paniculata. J Med Plants Res. 2010;4:197-202.

17. Rice-Evans CA, Miller NJ, Paganga G. Antioxidant properties of phenolic compounds. Trends Plant Sci. 1997;2:152-9.

18. Viszwapriya D, Prithika U, Deebika S, Balamurugan K, Pandian SK. In vitro and in vivo antibiofilm potential of '2,4-di-tert-butylphenol from seaweed surface associated bacterium Bacillus subtilis against group A streptococcus. Microbiol Res. 2016;191:19-31.

19. Nair RVR, Jayasree DV, Biju PG, Baby S. Anti-inflammatory and anticancer activities of erythrodiol- 3-acetate and 2,4-di-tertbutylphenol isolated from Humboldtia unijuga. Nat Prod Res. 2020;4:2319-22.
20. Rubab M, Chelliah R, Saravanakumar K, Barathikannan K, Wei S, Kim JR, et al. Bioactive potential of 2-methoxy-4-vinylphenol and benzofuran from Brassica oleracea L. var. capitata f, rubra (Red Cabbage) on oxidative and microbiological stability of beef meat. Foods. 2020;9:568.

21. Kim DH, Han SI, Go B, Oh UH, Kim CS, Jung YH, et al. 2-Methoxy-4vinylphenol attenuates migration of human pancreatic cancer cells via blockade of FAK and AKT signaling. Anticancer Res. 2019;39:6685669.

22. Jeong JB, Hong SC, Jeong HJ, Koo JS. Anti-inflammatory effect of 2-methoxy-4-vinylphenol via the suppression of NF-KB and MAPK activation, and acetylation of histone H3. Arch Pharm Res. 2011;34: 2109-16.

23. Woo SU, Jang HR, Chin YW, Yim H. 7-O-Methylwogonin from Scutellaria baicalensis disturbs mitotic progression by inhibiting Plk1 activity in Hep3B cells. Planta Med. 2019;85:217-224.

24. Saad MMG, Abou-Taleb HK, Abdelgaleil SAM. Insecticidal activities of monoterpenes and phenylpropenes against Sitophilus oryzae and their inhibitory effects on acetylcholinesterase and adenosine triphosphatases. Appl Entomol Zool. 2018;53:173-81.

25. Baldissera MD, Grando TH, Souza CF, Gressler LT, Stefani LM, da Silva AS, et al. In vitro and in vivo action of terpinen-4-ol, $\gamma$-terpinene, and $\alpha$-terpinene against Trypanosoma evansi. Exp Parasitol. 2016;162:43-8.

26. Baldissera MD, Souza CF, Dolci GS, Grando TH, Sagrillo MR, Vaucher RA, et al. Monoterpene alpha-terpinene induced hepatic oxidative, cytotoxic and genotoxic damage is associated to caspase activation in rats. J Appl Biomed. 2017;15:187-95.

27. Mangoyi R, Midiwo J, Mukanganyama S. Isolation and characterization of an antifungal compound 5-hydroxy-7,4'-dimethoxyflavone from Combretum zeyheri. BMC Complement Altern Med. 2015;15:405.

28. Wu MR, Hou MH, Lin YL, Kuo CF. 2,4,5-TMBA, a natural inhibitor of cyclooxygenase-2, suppresses adipogenesis and promotes lipolysis in 3T3-L1 adipocytes. J Agric Food Chem. 2012;60:7262-7269.

29. Guarrera $M$, Turbino L, Rebora A. The anti-inflammatory activity of azulene. J Eur Acad Dermatol Venereol. 2001;15:486-7.

30. Yilmaz S, Sova M, Ergün S. Antimicrobial activity of trans - cinnamic acid and commonly used antibiotics against important fish pathogens and nonpathogenic isolates. J Appl Microbiol. 2018;125:1714-27.

31. Abd El-Raouf OM, El-Sayed EM, Manie MF. Cinnamic acid and cinnamaldehyde ameliorate cisplatin-induced splenotoxicity in rats. J Biochem Mol Toxicol. 2015;29:426-31

32. Hafizur RM, Hameed A, Shukrana M, Raza SA, Chishti S, Kabir $\mathrm{N}$, et al. Cinnamic acid exerts anti-diabetic activity by improving glucose tolerance in vivo and by stimulating insulin secretion in vitro. Phytomedicine. 2015;22:297-300.

33. Balamurugan R, Stalin A, Aravinthan A, Kim JH. gamma-Sitosterol, a potent hypolipidemic agent: In silico docking analysis. Med Chem Res, 2015;24:124-30.

34. Sundarraj $S$, Thangam $R$, Sreevani $V$, Kaveri $K$, Gunasekaran $P$ Achiraman $S$, et al. $\gamma$-Sitosterol from Acacia nilotica L. induces G2/M cell cycle arrest and apoptosis through c-Myc suppression in MCF-7 and A549 cells. J Ethnopharmacol. 2012;141:803- 809.

35. Fujiwara GM, Annies V, de Oliveira CF, Lara RA, Gabriel MM, Betim FCM, et al. Evaluation of larvicidal activity and ecotoxicity of linalool, methyl cinnamate and methyl cinnamate/linalool in combination against Aedes aegypti. Ecotoxicol Environ Saf. 2017;139:238-44.

36. Bhardwaj M, Sali VK, Mani S, Vasanthi HR. Neophytadiene from Turbinaria ornata suppresses LPS-induced inflammatory response in RAW 264.7 macrophages and sprague Dawley rats. Inflammation. 2020;43:937-50.

37. Silva RO, Sousa FBM, Damasceno SRB, Carvalho NS, SilvaVG, Oliveira FRMA, et al. Phytol, a diterpene alcohol, inhibits the inflammatory response by reducing cytokine production and oxidative stress. Fund Clin Pharmacol. 2014;28:455-64.

38. Nakanishi T, Anraku M, Suzuki R, Kono T, Erickson L, Kawahara S. Novel immunomodulatory effects of phytanic acid and its related substances in mice. J Funct Foods. 2016;21:283-89. 
39. Oikawa N, Nobushi Y, Wada T, Sonoda K, Okazaki Y, Tsutsumi S, et al. Inhibitory effects of compounds isolated from the dried branches and leaves of murta (Myrceugenia euosma) on lipid accumulation in 3T3L1 cells. J Nat Med. 2016;70:502-9.

40. Rafatian G, Khodagholi F, Farimani MM, Abraki SB, Gardaneh M. Increase of autophagy and attenuation of apoptosis by salvigenin promote survival of SH-SY5Y cells following treatment with $\mathrm{H}_{2} \mathrm{O}_{2}$. Mol Cell Biochem. 2012;371: 9-22.

41. Mehan S, Rajput M, Dudi R, Ghimire K. Neuroprotective strategies of solanesol in mitochondrial impairment in experimentally induced Huntington disease. J Pharm Toxicol. 2018;1:3-7.
42. Bai Q, Yu J, Su M, Bai R, Katumata G, Katumata M, et al. Antioxidant function of solanesol and its inhibitory effect on tyrosinase. J Biomed Eng. 2014;31:833-6.

43. Huang ZR, Lin YK, Fang JY. Biological and pharmacological activities of squalene and related compounds: potential uses in cosmetic dermatology. Molecules. 2009;14:540-54.

44. Wang J, Huang M, Yang J, Ma X, Zheng S, Deng S, et al. Anti-diabetic activity of stigmasterol from soybean oil by targeting the GLUT4. Food Nutr Res. 2017;61:1364117.

45. Babu S, Jayaraman S. An update on $\beta$-sitosterol: A potential herbal nutraceutical for diabetic management. Biomed Pharmacother. 2020;131:110702.

\section{GRAPHICAL ABSTRACT}

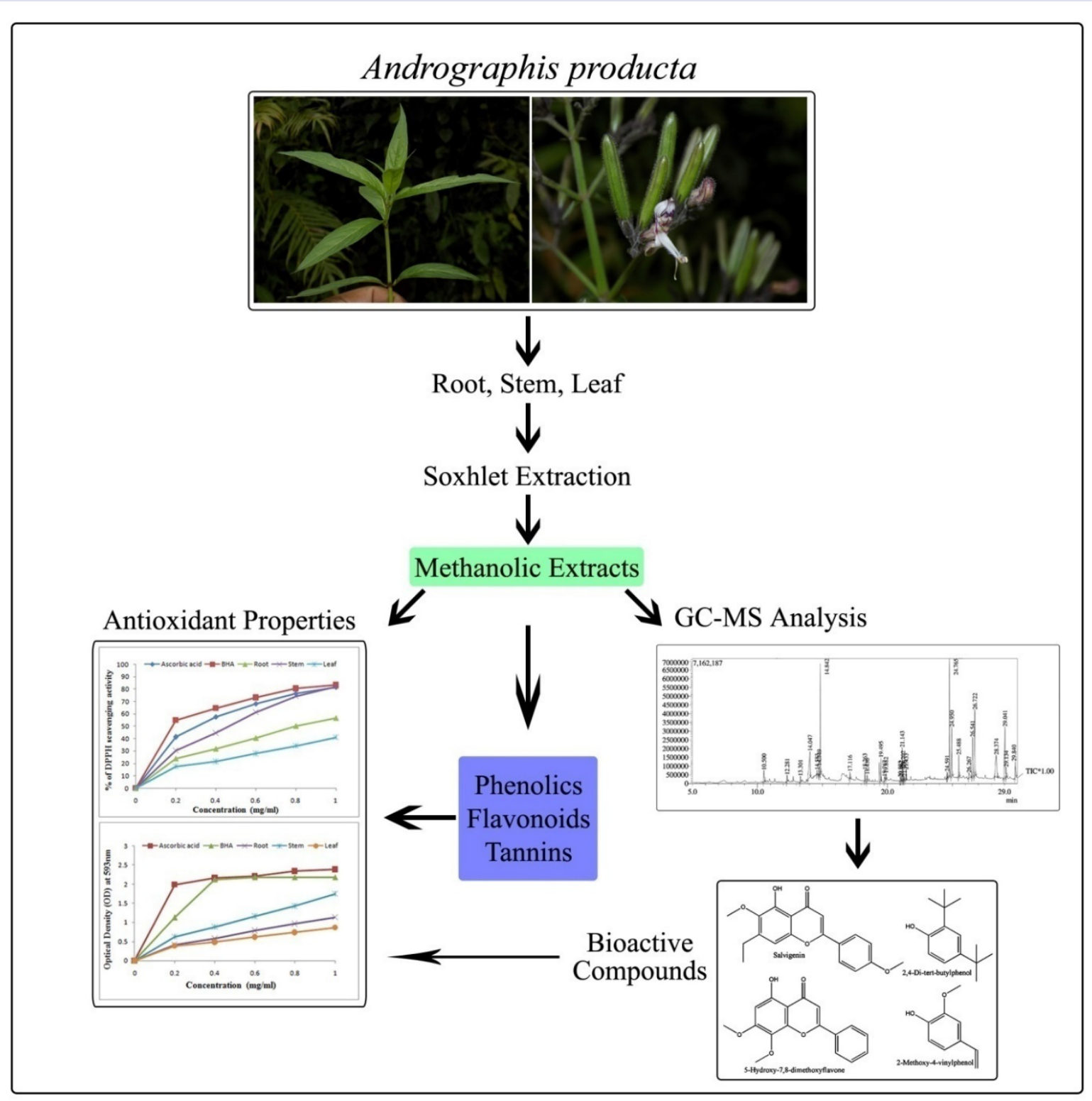




\section{ABOUT AUTHORS}

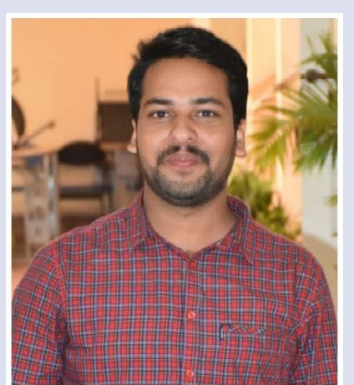

Dayanand Dalawai is research scholar at Department of Botany, Karnatak University, Dharwad, India. He has completed Master of Science in Botany from same university.

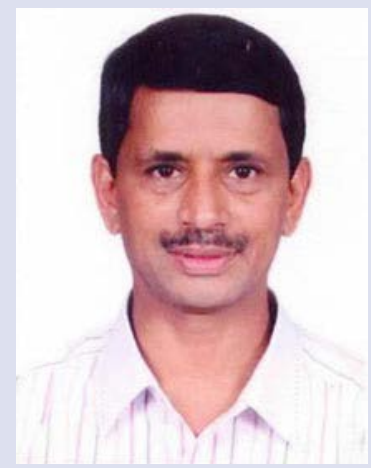

Hosakatte Niranjana Murthy professor in Department of Botany, Karnatak University, Dharwad, India, has obtained Ph.D. degree from the same university. He has tremendous passion for research and academics. Since 1986, Apart from his teaching experience of 34 years, he possesses extensive research experience in the area of plant biotechnology. Prof. Murthy has post-doctoral and collaborative research experience in many foreign research institutes. He has successfully completed more than 15 research projects funded by various agencies and guided several Ph.D. students. Prof. Murthy has published more than 200 research articles in international peer reviewed journals with high impact factor.

Cite this article: Dalawai D, Murthy HN. Chemical Profile and Antioxidant Properties of Andrographis producta (C. B. Clarke) Gamble. Pharmacog J. 2021;13(2): 475-85. 